\title{
A xiameni Gulangyu Közös Koncesszió története a 19-20. századi kínai-külföldi nyelvi és kulturális interakció tükrében
}

„A többi megálló közül Xiamen és Gulangyu (a helyi hokkien dialektusban Amoy és Kulangsu) voltak emlékezetesek. Kínai utunk során elöször hallhattuk a Szingapúrból ismerôs dialektus hangjait. Éveket töltöttem a megtanulásával választási sikereim érdekében, és öröm volt hallani úgy, ahogy egykor tanáromtól hallottam, a xiameni akcentussal, amit a háború elótti Fujian tartomány értelmisége használt nyugati üzletemberekkel és hittérítókkel való kapcsolatfelvétele során."

(Lee Kuan Yew, Szingapúr 1959-1990 közötti miniszterelnöke,)

\section{Bevezető}

Xiamen 厦门 (minnan E-mng ${ }^{2}$ ), régies nevén Amoy nagyváros Délkelet-Kínában, a Taiwani-szoros partján, Fujian 福建 tartomány déli részének, az ún. Minnan 闽南 régiónak a központja. Xiamen a taiwani lakosság többsége által is beszélt minnan vagy más néven hokkien dialektus hagyományos központja, és mint egykori fó kiinduló állomása a Délkelet-Ázsiába irányuló kínai kivándorlásnak, fontos szerepet játszik a Dél-kínai-tenger régiójának

Lee 2000: 686.

2 A szövegben előforduló minnan szavak az ún. peh-oe-ji romanizációs rendszer szerint vannak átírva. 
számos különböző részén letelepült hokkien nyelvú kínai közösségek történetében. Xiamen egyike volt az első ópiumháborút követóen a külföld számára legkorábban megnyitott kikötóknek, és a Xiamen fósziget közvetlen szomszédságában található apró Gulangyu-sziget 鼓浪屿 a 20. század elején egyike lett Kína két nemzetközi irányítás alatt álló közös koncessziós területének. Jelen tanulmány célja annak bemutatása, hogy Gulangyu szigete hogyan játszott központi szerepet a kínaiak, külföldiek és tengerentúli kínaiak közti, a Dél-kínai-tenger régióját behálózó nyelvi és kulturális interakcióban a 19. és 20. század során. Bár a tanulmány elsősorban nyelvi és kulturális szempontokra fókuszál, a gazdasági, kereskedelmi és politikai viszonyokat is röviden felvázolom. A tanulmányban vizsgált történelmi periódus az első ópiumháborútól (1839-42) a csendes-óceáni háború kezdetéig és a sziget Japán általi megszállásáig (1941) terjed, melyet követően az összes külföldi koncessziós terület visszakerült Kínához. Bár a Gulangyu Közös Koncesszió (Gulangyu Joint Concession, Gulangyu Gonggong Zujie 鼓浪屿公共租界) hivatalosan csak 1903-ban alakult meg, eddigre a sziget már nagyjából fél évszázada gyakorlatilag külföldi irányítás alatt állt.

A tanulmányhoz használt elsődleges források nagyrészt a korabeli Gulangyun tevékenykedő brit és amerikai hittérítők angol nyelvú feljegyzései. Az egyik legkorábbi leírás szerzője az ismert brit nyelvész és diplomata, Herbert Allen Giles, a Wade-Giles romanizációs metódus rendszerezője, aki Xiamen brit konzulja volt 1878-tól 1881-ig. ${ }^{3}$ Az angol nyelvú elsődleges források közül a leginkább részletes és átfogó az amerikai református hittérítő, Philip Wilson Pitcher 1912-ben kiadott In and about Amoy. Some historical and other facts connected with one of the first open ports in China címú múve, mely jelentős mennyiségú Gulangyuvel kapcsolatos anyagot tartalmaz. Ezen kívül nagy mennyiségú elsődleges forrást, nagyrészt magánleveleket publikált a Xiamen University Press 2010-ben az Old Gulangyu in Foreigners' Eyes címú gyújteményben, emellett brit archívumokban talált levelezéseket jelentetett meg a 2015-ben indult Journal of Gulangyu Studies (Gulangyu yanjiu 鼓浪屿研究) első két száma. ${ }^{4}$

Giles 1878.

4 Woodbridge 2015a, 2015 b. 
Xiamennel kapcsolatosan meglehetősen kevés átfogó angol nyelvú másodlagos szakirodalom lelhető fel. A leginkább figyelemreméltó és részletes közülük James Alexander Cook Bridges to Modernity: Xiamen, Overseas Chinese and Southeast Coastal Modernization, 1843-1937 címú PhD értekezése, melynek egyik fejezete külön foglalkozik Gulangyuvel. Manuel Rigger 2015-ben a Xiamen Egyetemen közzétett German Involvement in Xiamen After the First Opium War 1842-1917 címú MA szakdolgozatában a német jelenlét kontextusában kerül bemutatásra Gulangyu története.

Ami a kínai nyelvú elsődleges forrásokat illeti, 1995 és 2003 között a Kínai Népi Politikai Tanácskozó Testület (Zhongguo Renmin Zhengzhi Xieshang Huiyi 中国人民政治协㢗会议) adta ki a Gulangyu wenshi ziliao 鼓浪屿文史资料 (Gulangyui irodalmi és történeti anyagok) címú gyújteményt, amely nagy mennyiségú személyes beszámolót tartalmaz a sziget történetének jelentős eseményeiről, intézményeiről, személyeiről. Ez 2010-ben három kötetben újra kiadásra került Gulangyu UNESCO világörökségi státuszra való pályázása keretében. Általában Xiamennel foglalkozó, Gulangyuvel kapcsolatos elsődleges forrásokat is tartalmazó kiadványok nagy mennyiségben találhatók a Xiamen Egyetem könyvtárában, köztuik például a 22 kötetes Xiamen wenshi ziliao 厦门文史资料 (Xiameni irodalmi és történeti anyagok).

A kínai nyelvú másodlagos források közül a leginkább átfogó a nemrégiben kiadott Gulangyu lishi wenhua xilie 鼓浪屿历史文化系列(Gulangyu története és kultúrája sorozat). Ezt a tízkötetes sorozatot a Xiamen Egyetem adta ki 2010 és 2013 között, szintén az UNESCO világörökségi státuszért való jelentkezés keretében. Köztük a Xiamen történelmével évtizedek óta foglalkozó He Bingzhong 何丙仲 Gulangyu Gonggong Zujie (A Gulangyu Közös Koncesszió) címú kötete alapos leírást ad a nemzetközi település történetéról általában, míg a további kötetek egy-egy specifikus témával foglalkoznak (építészet, zene, oktatás stb.). A Gulangyu-kutatás legújabb fejleményei közé tartozik a Gulangyu Studies (Gulangyu yanjiu 鼓浪屿研 究) címú folyóirat elindítása 2015-ben. A korábbi másodlagos források közt 
említésre méltó a kínai történelem- és marxizmusszakértő, He Qiying 何其 颖 Gonggong zujie Gulangyu yu jindai Xiamen de fazhan 公共租界鼓浪 屿与近代厦门的发展 (A Gulangyu Közös Koncesszió és az újkori Xiamen fejlơdése) címú munkája.

\section{Történelmi háttér}

A fejlődési folyamat, melyen Gulangyu keresztülment, nem csupán azért volt különleges, mert ez volt az egyetlen „közös koncesszió” a Shanghai Nemzetközi Településen (Shanghai International Settlement) kívül. Ahhoz, hogy megértsük Gulangyu egyediségének egyéb aspektusait, először is szemügyre kell venni Xiamen geopolitikai helyzetét a tágabb dél-kínai-tengeri régió részeként, valamint Gulangyu speciális földrajzi és politikai státuszát mint kapu a szárazföldi Kína és Nanyang 南洋 (szó szerint „déli tenger[ek]”), vagyis Délkelet-Ázsia tengerparti területei közt.

Az első ópiumháború (1839-42) és a második világháború közti nagyjából száz év alatt a Dél-kínai-tenger régiója masszív gyarmati terjeszkedésnek és a különböző gyarmatosító nagyhatalmak közti rivalizálásnak volt terepe. A tárgyalt időszak alatt a hét gyarmatosító hatalom, mely területi érdekeltségekkel rendelkezett a régióban, a következő volt: Nagy-Britannia (Hongkong, Straits Settlements, Malájföld, Észak-Borneó, Sarawak, Brunei), Franciaország (Francia Indokína), Hollandia (Holland Kelet-India), Portugália (Makaó), Japán (Taiwan 1895-től), Spanyolország (Fülöp-szigetek 1898-ig) és az Egyesült Államok (Fülöp-szigetek 1902-től). Csupán két ország, a Sziámi Királyság (a mai Thaiföld) és a szárazföldi Kína őrizte meg hivatalosan függetlenségét. Gulangyun kívül három más koncessziós terület és egy bérelt terület volt található a délkelet-kínai partvidéken, mindegyikük brit vagy francia érdekeltségú volt. Az Amoy Brit Koncesszió (1851-1925) Gulangyuvel szemben Xiamen főszigetén múködött, gyakorlatilag egy kereskedőállomás szerepét betöltve, mivel a külföldi személyzet nagy része Gulangyun lakott. A Guangzhou (Kanton) városához tartozó Shamian-sziget (Shamian dao 沙面岛) adott otthont a kantoni brit és francia koncessziónak, 
bár egy a helyiek és a külföldiek közt kitört zavargás következtében a két koncessziós terület múködése meglehetősen korlátozott volt, és soha nem ért el a gulangyuihez hasonló fejlettségi szintet. ${ }^{5}$ A Guangdong tartománybeli Zhanjiang városához tartozó Guangzhouwan (Kouang-Tchéou-Wan 广州 湾) francia illetôségű bérelt területet 1899-től a második világháború végéig Francia Indokína részeként kormányozták. ${ }^{6}$

Hivatalosan 13 ország $^{7}$ volt képviselve Gulangyun a közös konceszszió alapításakor. Ezek között valójában három ország (Nagy-Britannia, az Egyesült Államok és Japán) voltak azok, amelyek a sziget fejlődésének egészére jelentős hatással voltak, míg a többi ország befolyása nagyrészt egy adott gazdasági területre korlátozódott (például Németország esetén ez a hajózás volt). ${ }^{8}$ Ami az Osztrák-Magyar Monarchia jelenlétét illeti, a rendelkezésre álló adatok szerint nagyjából 1869 körül alakult osztrák-magyar konzulátus a szigeten, de valójában mindig más ország konzulátusa (kezdetben a francia, később a brit) látta el a monarchia képviseletét. ${ }^{9}$ A monarchia egyetlen valóban funkcionáló koncessziós területe így az észak-kínai Tianjin 天津 városában múködött. A sziget kulturális fejlődésére az első évtizedekben döntő hatással voltak az ide érkező brit és amerikai hittérítők. Az oktatás első számú nyelve a koncessziós időszak egészében az angol maradt. A japánok Taiwan 1895-ös megszállását követően kezdték el befolyásukat kiterjeszteni a szigetre, mivel Dél-Fujian ekkortól kezdve az ún. „déli előrenyomulás” (nanshin 南進) stratégia következő célpontjává vált. 1900-ban egy - kétségkívül a japánok által felbérelt szerzeteseknek öltözött gyújtogatók által kiváltott incidens vezetett a Pitcher és mások által „Japanese Scare of 1900” („,1900-as japán ijedelem”) néven emlegetett eseménysorozathoz, melynek során a japán flotta egy rövid időre

\footnotetext{
Fei 1990: 297-299.

Long - Jing 2013: 19.

7 A régióban érdekelt hét fentebb említett gyarmatosító hatalmon kívül Németország, az Osztrák-Magyar Monarchia, Belgium, Svédország, Dánia és Norvégia. Valójában a kisebb országok képviseletét nagyrészt más nemzetek követségei látták el az időszak nagy részében.

Rigger 2015: 116-120.

9 He 2007: 18, erre hivatkozik Xiamen wenshi ziliao Vol. 3: 10.
} 
megszállta a Xiamen főszigetet és Gulangyut, majd brit és amerikai nyomásra végül letett a város tartós elfoglalásáról. Az 1902-ben megkötött, Gulangyu közös koncesszióvá alakításáról szóló szerződés jelentős részben a britek és amerikaiak azon szándékából fakadt, hogy a jövőben megelőzzék az ehhez hasonló konfliktusokat, és kordában tartsák a japán terjeszkedési ambíciókat. Japán ugyanakkor az elkövetkező évtizedekben békés eszközökkel tovább növelte befolyását Gulangyun. Ez megnyilvánult például a japán állampolgársággal rendelkező taiwaniak egyre növekvő számában, akik egyre jelentősebb szerepet kezdtek játszani a sziget gazdasági életében. A japán külügyminisztérium Ázsia-részlegének a szigeten lakó külföldiekrôl készült népszámlálási adatai (Shina zairyū honhōjin oyobi gaikokujin jinkō tōkei 支那在留本邦人及 外国人人口統計, Statisztika a Kínában lakó helyiek és külföldiek számáról) alapján a Gulangyun lakó taiwaniak száma az 1926-os 6753 főról 1935-re 10 625 főre növekedett, majd ezt követően 1937-re 7242-re csökkent. Ugyanakkor a taiwani lakosok száma messze meghaladta bármely más külföldi csoport lakosságszámát a vizsgált időszakban. A japán lakosok valaha regisztrált legmagasabb száma 412 fô volt 1937-ben, míg bármely más külföldi nemzetiségú csoport legmagasabb száma 1153 fó 1934-ben. ${ }^{10}$ A sziget irányításáért felelős GMC (Gulangyu Municipal Council) japán tagjainak száma szintén növekvő tendenciát mutatott az 1920-as években. ${ }^{11}$ Növekvő politikai és gazdasági befolyása ellenére ugyanakkor Japán a sziget 1941-es egyoldalú megszállásáig nem volt képes jelentős hatást gyakorolni annak oktatási rendszerére, melyet végig az angol nyelv dominált.

A régió fejlódésében döntő szerepet játszó, jelentős részben a nyugati gyarmatosításhoz kötődő folyamatok egyike volt a képzetlen kínai munkaeró (ún. kulik) tömeges kivándorlása a dél-fujiani régióból, különösen Xiamenből és környékéről, illetve a velük való kereskedelem. Xiamen délkelet-ázsiai kuli kivándorlásba, illetve kereskedelembe való bekapcsolódásának okai a Zheng 郑 klán által vezetett 17. századi mandzsuellenes küzdelmekhez vezethetôk vissza, melyek legismertebb alakja a Taiwanon

10 Wang 2015: 54.

11 He 2010: 59-62. 
máig nemzeti hősként tisztelt Koxinga (minnan Kok-sin-ia 国姓爷), más néven Zheng Chenggong 郑成功 volt. A Zheng klán csempészeti és kalózkodási tevékenységeihez a Xiamen főszigetet kezdte el bázisként használni, hogy elkerülje ezáltal a központi hatalom által jobban ellenőrzött, közel egy évezrede Dél-Fujian első számú kikötőjének számító Quanzhou 泉州 városát. Xiamen felemelkedése és központtá válása nagy múltú szomszédja, Quanzhou ellenében ezen időszaktól kezdődött. Bár a 17. század végére a Qing hatalom hivatalosan irányítása alá vonta Dél-Fujiant és Taiwant, a Zhengek Xiamen központú kereskedelmi birodalma a 19. századig domináns szerepet töltött be a dél-kínai-tengeri kereskedelemben. A régióba érkező első európaiak feljegyzései bizonyítják, hogy a kereskedelmi útvonalak és hálózatok mentén a kínai kivándorlás Dél-Fujianből Délkelet-Ázsiába már ekkoriban elkezdődött. ${ }^{12}$ Amikor a 19. század közepétól kezdetét vette a fokozott gyarmati terjeszkedés, és a kapitalizmus elōrehaladott formája megjelent a régióban, az európaiak nagy hasznát vették a biztos alapokon nyugvó kapcsolatoknak a délkelet-ázsiai hoklo lakosság ${ }^{13}$ és Dél-Fujian között az újonnan megnyitott ültetvények és bányák növekvő munkaerőigényének kielégítése érdekében.

12 Cook 1998: 23-61.

13 A „hoklo/hokkien”, illetve a „minnan” megnevezések tartalma némi magyarázatot igényel. A hoklo 福佬 a dél-fujiani származású kínaiak Délkelet-Ázsiában használt megnevezése, az általuk beszélt dialektust nevezik Délkelet-Ázsiában hokkiennek, mely Fujian tartomány neve a minnan dialektusban. A hoklo lakosság alkotja a malajziai, szingapúri, indonéziai és fülöp-szigeteki kínai lakosság többségét. A hokkien tehát a Xiamenben, környékén és a szomszédos Taiwanon beszélt, Kínában nagyrészt minnanhua 闽南话 (,déli min/dél-fujiani beszéd”) néven ismert minnan dialektus egy másik elnevezése, azt érdemes azonban megjegyezni, hogy Fujian tartományban a hokkienen kívül számos más dialektust - pl. mindong/keleti min, minbei/északi min és hakka dialektusokat - is beszélnek. Bár a kínaiak minnanhua alatt általában kifejezetten ezt a Xiamen központú dialektust értik, egyes szakértők a minnan dialektuscsoportba sorolják a Guangdong tartomány északkeleti részén beszélt teochew dialektust (chaozhouhua 潮州话) és Hainan szigetén, valamint Guandong és Dél-Zhejiang tartományok bizonyos részein beszélt kisebb min dialektusokat. Ezen dialektusok beszélői ugyanakkor általában különálló identitással rendelkeznek a kínai közösségeken belül, egyes délkelet-ázsiai országokban (pl. Thaiföld, Laosz, Kambodzsa) a teochew nyelvû lakosság többségben van a hokkien nyelvű lakossággal szemben. A tanulmányban délkelet-ázsiai kontextusban a hokkien, kínai kontextusban a minnan (dialektus) megnevezés lesz használatos a Xiamenből és környékéról származó nyelvváltozatra. 
A tömeges kivándorlás drasztikus hatással volt különösen a Xiamen környékén található ún. qiaoxiangokra 侨乡. A qiaoxiang elnevezés a tengerentúli kínaiak kínai nyelvú megnevezésének (huaqiao 华侨) és a xiang 乡 'szülőfalu' szónak a kombinálásából ered, utalva azon falvakra, ahonnan a kivándorolt kínaiak nagy része származott. Korabeli források, például Pitcher leírása szerint ezen falvak nagy részéből a 19. század végére gyakorlatilag a teljes munkaképes korú férfi lakosság kivándorolt a jobb megélhetés reményében. Gulangyu számára ugyanakkor még nagyobb változást jelentett a 20. század első évtizedeiben kezdődő ellentétes folyamat, melynek során a korábban kivándorolt huaqiao lakosság egy része elkezdett hazatérni elődei földjére, egy új társadalmi csoportot, az ún. guiqiao 扫侨 közösségeket létrehozva (a gui 归 'visszatérni' és a huaqiao szavak kombinálásából). Nagy részük ugyan a qiaoxiangba, elődei lakóhelyére tervezett visszatérni, de a kínai szárazföldön ekkoriban uralkodó társadalmi és politikai állapotok végül sokakat arra késztettek, hogy ehelyett a külföldi irányítás alatt álló, a szárazföldnél politikailag stabilabb és a modernizációban előbbre járó Gulangyut válasszák új lakhelyül. ${ }^{14}$

\section{Külföldi hittérítook és tengerentúli kínaiak - Gulangyu kulturális fejlődésének két szakasza}

Gulangyu nyelvi és kulturális fejlődése két korszakra osztható. Közülük az elsóben meghatározó szerepet játszottak a külföldi - nagyrészt protestáns brit és amerikai - hittérítők. Mivel fó céljuk a kereszténység terjesztése volt a helyi lakosság körében, a minnan dialektus megtanulása, továbbá egy standard latin betús írott minnan nyelv kialakítása és a vallási szövegek erre történő lefordítása kulcsfontosságú volt számukra. A hokkien-nyugati nyelvi és kulturális interakció kontextusában Gulangyu azonban inkább egy már a délkelet-ázsiai gyarmatokon megkezdett folyamat következó állomása volt,

14 Cook 1998: 62-105. 
mint annak kiindulópontja. Bár azt érdemes megemlíteni, hogy a legkorábbi hokkien-nyugati szótárrészletek és romanizációs kísérletek 16-17. században a Fülöp-szigeteken tevékenykedő spanyol Domonkos-rendi szerzetesek munkái ${ }^{15}$ a Gulangyun zajló interakciós folyamat előfutárai a délkelet-ázsiai brit gyarmatokon kiadott hokkien-angol tankönyvek és szótárak voltak, szerzőik pedig protestáns hittérítők; a legkorábbi ezek közül Walter Henry Medhurst Dictionary of the Hok-këèn Dialect of the Chinese Language, According to the Reading and Colloquial Idioms címú múve (1832). Az első ópiumháború (1839-42) után megnyílt a kapu a külföldi hittérítők számára, hogy munkájukat a kínai kikötővárosokban folytassák. A Xiamenbe érkező külföldiek nagy része a túlzsúfolt fősziget helyett az élhetőbb, kellemesebb klímájú Gulangyut választotta. A minnan romanizáció, helyi nevén a peh$o e-j i$ 白话字 (,,beszélt nyelvi írás”) fejlődésében jelentős szerepet játszó Gulangyun tevékenykedő szerzetesek között megemlítendő Elihu Doty, ${ }^{16}$ John MacGowan ${ }^{17}$ és John van Nest Talmage. Bár nem a feltalálója és egyetlen fejlesztője az írásnak, Dr. Talmage-ot gyakran illetik a ,peh-oe-ji atyja” elnevezéssel. A közel ötven év alatt, amit Gulangyun töltött, hatalmas energiát fektetett a peh-oe-ji rendszerezésébe és annak terjesztésébe a helyi lakosság körében. 1894-ben, két évvel halála után került kiadásra E-mng-im e ji-tian 厦门音的字典 (Axiameni dialektus szótára) címú múve, melyet ma is sokan a peh-oe-ji alapmúvének tartanak. ${ }^{18}$

A protestáns missziók mellett katolikus hittérítés is zajlott Gulangyun, nagyrészt Domonkos-rendi szerzetesek által, bár befolyása jóval kisebb volt a brit-amerikai protestáns hittérítéshez képest. A Fülöp-szigeteket a 16. században gyarmatosító spanyolok évszázadok óta jelen voltak a dél-kínai

15 Zhan - Lin 2007: 221. Az említett kéziratok a következők: Francisco Márquez: Gramática española-china, anonim kéziratok a manilai Santísimo Rosario Domonkos-rendi egyházi tartományi archívumból: Diccionario China - Español, dialecto de Emuy; Diccionario Español - China, dialecto de Emuy; Vocabulario de lengua Española, dialecto de Emuy. Hivatkozott forrás: González, José María: Historia de las Misiones Dominicanas de China, Tomo I-V, Madrid, 1955-1967.

16 Doty 1853.

17 MacGowan 1869.

$18 \quad$ Liu 2013. 
partvidéken, a hittérítésben kezdettől fogva elsősorban a Domonkos-rendi szerzetesek voltak aktívak. Fujian, Formosa (Taiwan), Japán és Tonkin (Vietnam) egyaránt a manilai központú Sántisimo Rosario Domonkos-rendi egyházi tartomány része volt. A délkelet-kínai partvidéken azonban fő regionális központjuk nem Dél-Fujian, hanem az észak-fujiani Fuzhou 福州 városa volt. 1883-ban alakult meg az önálló xiameni egyházkörzet, 1914-ben központja Gulangyu lett, ahol 1917-ben gótikus stílusú katolikus templom épült. ${ }^{19}$

A hittérítők - vallási tevékenységükön kívül - iskolák alapításával nagyban hozzájárultak a szigeten a modern nyugati oktatás meghonosításához. A 20. század elején Gulangyu büszkélkedhetett Kínában a legtöbb egy négyzetkilométerre jutó iskola rekordjával, az ország első óvodája itt nyílt, a sport- és zeneoktatásban is úttörő szerepet játszott. Kínában először Gulangyun zajlott zongoraoktatás, a szigeten jelenleg is elismert zenei konzervatórium múködik. ${ }^{20}$

Gulangyu fejlődésének második szakasza a 20. század első évtizedeiben kezdődött, és a visszatérő tengerentúli kínaiak érkezése határozta meg. Ezen kínaiak nagyrészt maguk vagy még elődeik vándoroltak ki Délkelet-Ázsiába a szegénység elől menekülve, ahol aztán sokan közülük kereskedelemből, vállalkozások indításából jelentős vagyont halmoztak fel. A 20. század elejére a délkelet-ázsiai gyarmatokon a kínaiak alkották a városi középosztály jelentós részét, átmeneti réteget képezve a nyugati hatalmi elit és a nagyrészt földmúvelő helyi lakosság közt. Ahogy a kínai patrióta eszmék terjedni kezdtek a tengerentúli kínaiak köreiben is, egyre többen közülük elégedetlenné váltak a nyugati elit által korlátozott politikai lehetőségeikkel. Az ősök dél-fujiani szülőföldjére való visszatérés, a Kína modernizációjához való hozzájárulás a gyarmatokon megszerzett ismeretekkel egyre vonzóbbá vált sokak szemében. A visszatérés ugyanakkor többek számára csalódással járt, Dél-Fujian ugyanis ebben az időben Kína más részeihez hasonlóan hadurak és banditák állandó harcainak színtere volt, az elmaradottság és

\footnotetext{
$19 \quad$ Lin 2002.

$20 \mathrm{Xu}-$ Cheng 2012.
} 
törvénytelenség jellemezte. Ez alól Xiamen főszigete sem volt kivétel, az apró, külföldiek által irányított Gulangyu azonban ekkor már évtizedekkel előbb járt a modernizációban. Nem meglepő ezért, hogy sokan a gazdag tengerentúli kínaiak közül Gulangyut választották lakhelyül. A sziget fejlődése innentôl kezdve új irányt és tartalmat kapott, a visszatelepülő kínaiak, bár eleinte fóleg saját villáik építésével foglalkoztak, az 1920-as évekre egyre nagyobb szerepet kezdtek vállalni Xiamen és Dél-Fujian modernizációjában, Gulangyut ezen modernizációs törekvések központjává téve.

A tengerentúli kínaiak elképzelései Kína modernizációjával kapcsolatban bizonyos szempontokból nézve különböztek a szárazföldi Kínában ekkoriban elterjedt elképzelésektől. Egyrészt a gyarmatokon megszerzett tapasztalataik révén szárazföldi kortársaik nagy részéhez képest jártasabbak voltak a modern nyugati tudományokban, technikában, kormányzásban, a nyugati nyelvekben és kultúrában. Másrészt viszont társadalmi helyzetük, mint a nyugati hatalmi elit által politikai önmegvalósításában korlátozott etnikai kisebbség, szkeptikusabbá tette ôket a nyugati értékekkel kapcsolatban, és kínai identitásuk hangsúlyozása érdekében - fogékonyabbá a hagyományos kínai ideológiákra (különösen a konfucianizmusra). A szárazföldön a május 4-e mozgalmat (1919) követően ezzel szemben egyre inkább a hagyományos értékeket elvető, átfogó társadalmi reformokat, fokozott nyugatosítást sürgetô eszmék váltak elterjedtté. ${ }^{21}$

A Xiamenbe érkező vezetô tengerentúli kínai értelmiségiek, mint Lim Boon Keng (Lin Wenqing 林支庆) és Tan Kah Kee (Chen Jiageng 陈嘉 庚) a „3K”-ként (kozmopolita, kereskedelmi, konfuciánus; angolul Cosmopolitan, Commercial, Confucian) összefoglalható megközelítés hívei voltak az ország modernizációjának kérdésében. ${ }^{22}$ Ezen elvek szintézise úgy öszszegezhető, hogy egyrészt fontosnak tartották a nyitottságot a nyugati tudomány és technika átvétele iránt Kína fejlődése érdekében, másrészt hangsúlyozták a konfucianizmus mint erkölcsi értékrendszer propagálását a nyugati társadalmi minták túlzott mértékú átvétele ellenében. A „kereskedelmi” elem

\footnotetext{
21 Cook 1998: 1-22.
}

22 Cook 1998: 164. 
azt jelentette, hogy bár támogatták a konfucianizmust mint erkölcsi értékrendszert, de elutasították a konfucianizmushoz köthetô, évszázadokon át berögzült, gyakorlatiatlan oktatási módszereket, helyettük a modern, gyakorlatias, fóként gazdasági ismeretekre épító oktatást támogatva. ${ }^{23}$

Az 1920-as évekre a tengerentúli kínaiak modernizációs törekvéseinek jelentősége nyelvi és kulturális szempontból leginkább az általuk alapított és támogatott iskolák számában és színvonalában nyilvánult meg. 1934-ben Xiamen 39 általános iskolája közül 17-et alapítottak és/vagy támogattak tengerentúli kínaiak, közülük három - a Xunyuan Study (Xunyuan Zhai 寻源斋), a Yude Elementary (Yude Xiaoxue 毓德小学) és a Fumin Elementary (Fumin Xiaoxue 福民小学) - Gulangyun múködött. ${ }^{24} 1934$ augusztusában tíz magánkézben lévő középfokú oktatási intézmény volt Xiamenben, öt közülük Gulangyun: az Anglo-Chinese High School/College (Ying-Hua Zhongxue/Shuyuan 英华中学 / 书院), a Minnan Vocational High (Minnan Zhizhong 闽南职中), a Yude Girls' High (Yude Nüzhong 毓德女中), a Ciqin Girls' High (Ciqin Nüzhong 慈勤女中) és a Yangyuan High School (Yangyuan Zhongxue 养元中学). ${ }^{25}$

Az Angol-Kínai Kollégium (Anglo-Chinese College) 1898-ban alakult, a London Hittéritő Társaság (London Missionary Society) és az Angol Presbiteriánus Egyház (English Presbyterian Church) irányítása alatt állt, magas színvonalú angol nyelvú oktatása a délkelet-ázsiai kínai közösségekből is számos tanulót vonzott a szigetre. ${ }^{26} \mathrm{~A}$ kollégiumban használt tankönyvek nagy részét külföldról importálták. Az, hogy a szigeten általában az angol volt az oktatás fó nyelve, nemcsak a brit-amerikai térítooi hagyománynak volt köszönhető, hanem annak is, hogy a sziget tengerentúli kínai lakossága nagyrészt brit, illetve amerikai irányítás alatt álló gyarmati területekról érkezett (elsôsorban a Szingapúrt, Malakát és Penangot is magába foglaló Straits Settlementsről és a Fülöp-szigetekről), így már szülőföldjükön is angolul folytatták tanulmányaikat. ${ }^{27}$

\footnotetext{
Cook 1998: 436-438.

Wang 1996: 136-139.

Wang 1996: 81.

Cook 1998: 179-180.

$\mathrm{Xu}$-Cheng 2012: 221-225.
} 
A Gulangyuvel szemben a Xiamen fószigeten található Tongwen Intézet (Tongwen Shuyuan 同文书院) jó példája volt annak, ahogy a tengerentúli kínaiak modernizációs elképzelései megvalósultak az oktatásban. A Tongwen Intézetet A. Johnson Burlingame amerikai konzul, a GMC-tag ${ }^{28}$ taiwani filantróp, Lin Erjia 林尔嘉 és fülöp-szigeteki kínaiak egy csoportja alapította 1898-ban. Az intézet tantervében szerepelt angol nyelv, brit-amerikai irodalom, számos természettudományos és gazdasági tárgy, valamint gépírás - mind angolul oktatva külföldi tankönyvek segítségével -, továbbá a konfuciánus klasszikusokon alapuló erkölcstan mandarin nyelven tanítva. ${ }^{29}$

A Xiamen Egyetem (XMU) megalapítása 1921-ben a szingapúri kínai Tan Kah Kee által minden bizonnyal a tengerentúli kínaiaknak az oktatás terén elért legnagyobb sikere volt. A kezdetben Lim Boon Keng által vezetett Xiamen Egyetem a Délkelet-Ázsiából visszatérô kínaiak fô szellemi központja lett Kínában. Lim konfuciánus újjáéledést támogató ideológiája ellen azonban kritikus hangok is megjelentek. 1926 szeptemberétől a korabeli kínai szellemi élet két meghatározó alakja, Lu Xun 鲁迅 és Lin Yutang 林语 堂 is munkát vállalt a Xiamen Egyetemen, azonban Lim szellemi irányvonalával szembeni elégedetlenségük miatt 1927 elején mindketten távoztak. A penangi születésú volt XMU-diák, Tan Yeok Song 陈育崧 szerint, aki maga is Lim kritikusai közé tartozott, Lu és Lin anakronisztikusnak, a valósággal teljesen összeegyeztethetetlennek látták elveit. ${ }^{30} \mathrm{~A}$ konfliktus jó példája a korabeli szárazföldi születésú értelmiségiek és az egyetem tengerentúli kínai vezetôsége közti ideológiai különbségeknek. A következő idézet jól példázza Lim elkötelezettségét a konfuciánus értékek mellett:

„A konfucianizmus nem egy vallás, ha vallás alatt valamiféle hitvallást értünk, ami által az emberek kinyilvánítják hitüket természetfeletti dolgokban és lényekben. De ha vallás alatt egy törvényrendszert értünk, amely elóírja az emberi felelősségeket

28 GMC (Gulangyu Municipal Council) vagy KMC (Kulangsu Municipal Council), Gulangyu Városi Tanács, a közös koncesszió végrehajtó szerve, kínai neve Gongbuju 工部局 volt.

29 Wang 1996: 94.

30 Tan 1970: 50. 
és kötelességeket, akkor a konfucianizmus egyike a legmagasabb szintû vallásoknak... Összehasonlítva a kereszténységgel és annak megfelelőjével, a buddhizmussal, a konfucianizmus a messzemenőkig a jövő vallása. Európa tudósai nyíltan gyakorolják alaptanait, és bár magukat nem nevezik konfuciánusnak, ez csak mellékes dolog." ${ }^{31}$

\section{Társadalmi rétegződés a közös koncesszión}

He Bingzhong Gulangyu gonggong zujie (A Gulangyu Közös Koncesszió) címú múvében Gulangyu társadalmát három részre bontja: felső osztály (shangceng 上层), fôtest (zhuti 主体) és periféria (bianyuan 边缘). Elmélete szerint a felső osztály a szigeten állomásozó külföldi hivatalnokokból, hittérítőkből, doktorokból, a külföldi követségek és vállalatok magas rangú kínai alkalmazottaiból, valamint jómódú külföldi és kínai kereskedőkből állt. Megjegyzi továbbá, hogy a sziget kulturális fejlődésére nagy befolyással bíró gazdag tengerentúli kínaiak és taiwaniak mind e csoport részét képezték. A társadalom főtestét a külföldi diplomáciai intézmények alkalmazottai, tanárok és diákok, iparosok, közép- és kiskereskedők alkották. Az ún. periféria azon őslakosokból állt, akik továbbra is halászatból és mezőgazdaságból tartották el magukat, illetve a szigetre érkező alacsony képzettségú munkaerôből. ${ }^{32}$

Ha J. A. Cook a szigeten fellelhető identitáscsoportokra fókuszáló leírását vesszük alapul, a sziget társadalma három csoportra osztható, a külföldi (nem kínai etnikumú) lakosságra, a külföldi állampolgárságú tengerentúli kínaiakra, akik egyfajta átmeneti réteget alkottak a nem kínai etnikumú külföldiek és a „szárazföldi kínaiak”33 között, s ez utóbbiak alkották a harmadik

\footnotetext{
Lim 1904: 29.

32 He 2010: 104-105.

33 Ebben a kontextusban a „szárazföldi kínaiak” kifejezés a mai „szárazföldi Kína” társadalmi-politikai fogalmával egybeeső módon lesz használva, tehát Taiwan, Hongkong és Makaó kizárásával, de a Xiamen fősziget és Gulangyu magába foglalásával.
} 
csoportot. A szárazföldi kínaiak oktatási és anyagi háttere közt azonban igen jelentős eltérések voltak, hiszen voltak közülük, akik hasznot tudtak húzni a sziget magasan fejlett oktatási rendszeréből, mások pedig már a jobb lehetőségek keresése érdekében érkeztek a nemzetközi településre.

Egy példa erre Lu Zhuangzhang 卢意章章 (1854-1928), aki a ma Xiamen szárazföldi részéhez tartozó Tong'anban 同安 született, és a kínai nyelv fonetikus átírásának úttörőjeként vált ismertté. Az 1870-es években Gulangyun együtt dolgozott John MacGowannel és H. A. Giles-szal azok szótárprojektjén, és később maga is három különböző fonetizációs rendszert dolgozott ki a mandarin, a minnan és más kínai dialektusok leírására. Közülük az elsốt az 1892-ben kiadott Yi mu liaoran chujie 一目了然初阶 címú múvében publikálta, amit mint a legkorábbi kínai szerzó által kiadott fonetizációs rendszert tartalmazó múvet ma a nyelv- és írásreform mozgalom (yuwen gaige yundong 语文改革运动) kiindulópontjának tekintenek Kínában. Az 1920-as években ez a mozgalom vezetett a Taiwanon máig használt zhuyin, más néven bopomofo fonetizációs rendszer bevezetéséhez Kína-szerte, illetve a szárazföldi Kínában ma használt latin betûs hanyu pinyin létrehozását is e mozgalom eredményének tekintik. ${ }^{34}$ Szintén említésre méltó a Gulangyun született Zhou Bianming 周辨明 (Chiu Bien-ming 1891-1984), egy kínai protestáns lelkész fia, aki tanulmányait a sziget Xunyuan Akadémiáján kezdte, majd Shanghaiban 上海, Pekingben, Hamburgban, Oxfordban és a Harvardon folytatta, mielőtt visszatért Xiamenbe, hogy az újonnan alapított Xiamen Egyetemen vállaljon munkát. Az egyike volt az elsőknek, akik a minnan dialektus történeti fonológiájával és annak a közép-kínaihoz való viszonyával foglalkoztak. Az egyetem viharos történetében is fontos szerepet játszott a kínai-japán háború idején, amikor az intézmény először Gulangyure, majd a nyugat-fujiani Changting megyébe (Changting xian 长汀县) lett áthelyezve. A polgárháborút követően haláláig nagyrészt Szingapúrban élt és dolgozott. ${ }^{35}$

34 Hong - Zhan 2011: 1-14, Xu 2000.

35 Hong - Zhan 2011: 15-26. 
Felmerül a kérdés, hogy ha a sziget lakosságát kínaiakra, nem kínai etnikumú külföldiekre és a köztük speciális középréteget képező tengerentúli kínaiakra bontjuk, akkor a szigeten élő taiwani lakosságot hova soroljuk, akik - ahogy azt korábban jeleztük - létszámukban felülmúltak bármilyen más külföldi állampolgárságú csoportot. A taiwaniak a tengerentúli kínaiakkal ellentétben nem hozták magukkal az etnikai kisebbségi státuszból eredó tapasztalatokat, azonban a gyarmatosítást és a politikai lehetőségekben való korlátozottságot ugyanúgy megtapasztalták a japán uralom alatt, tehát leginkább egyfajta átmenetet képeztek a tengerentúli és a szárazföldi kínaiak között. Nagyrészt japán vállalatok alkalmazásában gazdasági célból tevékenykedtek a szigeten, bár egyesek közülük a sziget szellemi fejlődésében is szerepet játszottak. A költő, filantróp és a GMC kínai tagjának szerepét sok éven át betöltő taiwani Lin Erjia a sziget kulturális életének egyik legmeghatározóbb figurája volt a 20. század első évtizedeiben. Sok egyéb tevékenység mellett a Szövetség az Új Kínai Írás Népszerúsítéseért (Zhonghua Xin Zi Cujinhui 中华新字促进会, 1920) ${ }^{36}$ és a Szövetség a Fonetizáció Kutatásáért (Qieyin Yanjiuhui 切音研究会, 1920) alapításával támogatta Lu Zhuangzhang munkáját. ${ }^{37}$

A külföldiek számukat tekintve kevesen voltak, de gyakorlatilag abszolút hatalommal rendelkeztek a sziget ügyei felett egészen a kínai patriotizmus és a tengerentúli modernizációs mozgalmak 1920-as évekbeli megerősödéséig. Bár a külföldiek már közvetlenül az ópiumháború után elkezdtek letelepedni Gulangyun, az 1878-ban alapított Gulangyu Road and Cemetery Fund Committee (GRCFC, „Gulangyu Út és Temető Alap Bizottsága”) volt az első hivatalos külföldi önigazgatási szervezet. Ennek oka az volt, hogy bár a külföldiek a fószigettel szembeni relatív élhetősége miatt választották Gulangyut, a nyugati standardokhoz képest továbbra is elmaradottnak és egészségtelennek ítélték a szigeten uralkodó állapotokat, így a bizottság feladata lett a modernizációs projektek, úgymint az út- és csatornahálózat, valamint a korszerú temetôk kiépítésének megszervezése. Bár a sziget

\footnotetext{
$36 \quad$ Xu 2000: 71.
}

37 Xu 2000: 72. 
a közös koncesszió 1903-as megalapításáig hivatalosan kínai fennhatóság alatt maradt, ez inkább jelképes volt, hiszen eddigre már évtizedek óta gyakorlatilag a GRCFC irányítása alatt állt. Az aránytalan külföldi befolyást jól mutatja, hogy a közös koncesszió törvényhozó szerve, a kezdetben általában 6-7 fốt számláló GMC (Gulangyu Municipal Council) tagjai közt egyetlen kínai etnikumú képviseló részvétele volt engedélyezett. ${ }^{38}$

A tengerentúli kínaiak, csakúgy, mint a szigeten tartózkodó nyugatiak és japánok, külföldi állampolgársággal rendelkeztek, de faji alapon voltak elkülönítve a nem-kínai etnikumú külföldiektől, ${ }^{39}$ és számukra - a közös konceszszió alapító okirata (Land Regulations for the Settlement of Kulangsu, Amoy) szerint - nem volt engedélyezett a városi tanácsi választáson való indulás vagy szavazás. Egy R. W. Mansfield xiameni brit konzul által 1902. február 1-jén közzétett jelentés ${ }^{40}$ tanúsága szerint a japán konzul volt az egyetlen, aki a külföldi állampolgársággal rendelkező kínaiak bevonását támogatta a közös koncesszió adminisztratív procedúráiba, valószínúsíthetôleg a japán állampolgársággal rendelkező taiwaniak magas száma okán. Végül egy a xiameni daotai 道台 (körzeti legfelsőbb hivatalnok a Qing-korban) által megbízott kínai tag részvételét engedélyezték a tanácsban.

Ironikus módon, a tengerentúli kínaiak, akik azért hagyták maguk mögött a délkelet-ázsiai gyarmatokat, mert ott csalódottak voltak politikai korlátozottságuk miatt a nyugati hatalmi elit által, azáltal, hogy a szárazföldön fekvő qiaoxiang helyett Gulangyu biztonságát és relatív fejlettségét választották, sok szempontból a gyarmatokon tapasztalttal azonos helyzetbe kerültek. A fő különbség ugyanakkor az volt, hogy itt nem voltak etnikai kisebbség

38 He 2010: 59-62, a városi tanácstagok listája évenkénti lebontásban: Xiamen wenshi ziliao Vol. 16.

39 Woodbridge 2015b: 9: „In the above clause, the term 'foreign' is to be interpreted as meaning of persons not of Chinese race, and does not include persons of the race who may by birth or naturalization abroad have become the subjects of foreign countries." [A fenti záradékban a „külföldi” mint nem a kínai rasszhoz tartozó személy értendő, és nem foglalja magába a szóban forgó rasszhoz tartozó azon személyeket, akik születés vagy honosítás által külföldi országok állampolgárai lettek.] Idézve a Land Regulations for the Settlement of Kulangsu, Amoy címú dokumentumból.

40 Woodbridge 2015b: 6-7, az idézett dokumentum: Report on Draft Regulations and Byelaws for the Settlement of Kulangsu, Amoy (The National Archives of the UK: FO 676/16). 
státuszban, így a lakosság többségének támogatására számíthattak politikai önmegvalósításra irányuló elképzeléseik kivitelezésekor. Az első évtizedekben filantróp tevékenységekkel igyekeztek javítani a helyiek életkörülményein, például iskolák alapításával és az oktatás népszerúsítésével, nyilvános kertek építésével. A patrióta eszmék 1920-as évektől kezdődő rohamos terjedése folytán a Gulangyun éló tengerentúli kínaiak egyre határozottabban kezdték el követelni politikai jogaikat, elsősorban a városi tanácsban a kínai lakosság kiegyenlítettebb módon történő reprezentálását. Az 1920as években megalakult a szigeten a Kínai Adófizetők Szövetsége (Huaren Nashuizhe Hui 华人纳税者会), mely a kínai lakosság fó érdekképviseleti szervezete lett, valamint létrejött a Felmenői Falvak Megmentéséért Mozgalom (Ancestral Village Salvation Movement/AVSM, Minqiao Jiuxiang Yundong 闽侨救乡运动), amely elsősorban a dél-fujiani régió modernizációját túzte ki célul. A külföldiek és a kínaiak közti viszony az 1925. május 30-i shanghai-i incidens után vált különösen feszültté (a Shanghai Nemzetközi Településen ezen a napon erőszakossá fajuló külföldiellenes tüntetésekre került sor, melynek a brit és kínai rendfenntartó erók sortüze vetett véget, s a több halálos áldozat híre újabb tüntetési hullámokat indított el Kína-szerte.) Ahogy a Xiamenben érdekelt brit vállalatok és a Kínában tartózkodó brit hivatalnokok közti korabeli levelezésekből kiderül, a külföldi kereskedők aggódni kezdtek, hogy bojkottálják óket vagy tulajdonukat rongálás éri a növekvő külföldiellenesség közepette. Ezen okból ők maguk kérték szélesebb körú politikai jogok garantálását Gulangyu kínai lakosságának. ${ }^{41}$ 1926-ban így egy kiegészítés került a közös koncesszió alapító okiratába, mely a következőképp hangzott:
„A Városi Tanács álljon kilenc főből, öt külföldiből, akik közül nem több mint egy legyen kínai származású, továbbá négy kína- iból, akiket a jogosult választók szavazócédulákkal válasszanak

41 Woodbridge 2015b: 20-24. Az idézett dokumentumok: Amoy Intelligence Report for the halfyear ending 18 September 1926, p. 217 (The National Archives of the UK: FO 228/3281), Boyd \& Co. to H. H. Bristow, 31 December 1927 (The National Archives of the UK: FO 228/3895), H. H. Bristow to His Majesty's Minister, Peking, 5 February 1928 (The National Archives of the UK: FO 228/3895). 
az évi általános gyúléseken - a négy kínai tagot a kínai adófizetők gyúlésén, az öt külföldi tagot a külföldi adófizetôk gyúlésén." ${ }^{2}$

\section{Alternatív modernizáció és a központi kormány}

Az 1920-as évekre a Guomindang (GMD) hatalma konszolidálódott a kínai szárazföldön. Xiament 1924-ben szabadították föl a hadurak uralma alól a GMD csapatai, ami pozitív reakciókat váltott ki Gulangyu tengerentúli kínai közösségeiben. A befolyásos tengerentúli kínaiak, akiknek tevékenysége eddig Gulangyun saját villáik építésére korlátozódott, innentól kezdve energiájukat és anyagi forrásaikat a xiameni várostervezésre összpontosíthatták. Xiamen az évtized végére, története során először, jelentős modernizációs folyamaton ment keresztül, úthálózata és középületei kiépülttek. A tengerentúli kínaiak elsősorban a nyugatiak által modernizált délkelet-ázsiai gyarmati nagyvárosokat vették mintául Xiamen modernizációjához. Az ezen időszakból származó épületek (például a Xiamen Egyetem korai épületei) így nem meglepő módon egyszerre tükröznek dél-fujiani, nyugati és délkelet-ázsiai hatásokat. A nankingi központi kormány szerepét eleinte pozitívan értékelték a tengerentúli kínaiak, akiknek fő aspirációja szintén egy erôs, egységes, lakosainak érdekeit megvédeni képes Kína megteremtése volt. Ugyanakkor egyrészt, mivel a dél-fujiani lakosság nagy részének életkörülményei továbbra sem javultak jelentősen, másrészt, mivel a központi kormány továbbra sem mutatott elég határozottságot a fokozódó japán expanziós törekvésekkel szemben, a vele szembeni elégedetlenség egyre növekedett. ${ }^{43}$

42 Woodbridge 2015b: 19. „The Municipal Council shall consist of nine persons, five foreigner, of whom not more than one shall be of Chinese descent, and four Chinese, who shall be elected by ballot of qualified voters at the annual general meetings - the four Chinese members by the meeting of Chinese ratepayers, and the five foreign members by the meeting of foreign ratepayers." - Land Regulations for the Settlement of Kulangsu Amoy, [October 1926 (with proposed amendments inserted), p. 3.].

43 Cook 1998: 384-398. 
Az AVSM ambíciói - a Kínai Adófizetôk Szövetségével ellentétben jóval túlnyúltak a gulangyui kínai lakosság érdekeinek képviseletén. Egyik fó, végül soha meg nem valósult projektjük egy a Xiament a szomszédos Zhangzhouval 漳州 és Dél-Fujian nyersanyagokban gazdag belsőbb részeivel (Longyan 龙岩 és környéke) összekötő vasúti hálózat megépítése volt. A Zhangzhou-Longyan vasutak és bányák megszervezéséért létrehozott irodát (Zhang-Long lu kuang choubeichu 漳龙路矿筹备处) 1933-ban Gulangyun alapította meg a tengerentúli közösség két befolyásos vezetője, a fülöp-szigeteki születésű Li Qingquan 李清泉 és a holland kelet-indiai (ma Indonézia) születésû Huang Yizhu 黄奕住. ${ }^{44}$ Li Qingquan még ennél is tovább ment, amikor egy tengerentúli kínai irányítás alatt álló speciális gazdasági zóna létrehozását kezdte el sürgetni Dél-Fujianben. A központi kormánynyal való feszültségek az 1933-as fujiani lázadásban (Min bian 闽变) érték el tetôpontjukat. 1931-ben Mandzsúria Japán általi megszállását követóen a kormány által tanúsított megbékéló magatartás és a január 28-i incidens 1932-ben (összecsapások sorozata kínai és japán egységek közt Shanghaiban) feldühítette a tengerentúli kínai vezetôket és több befolyásos katonai vezetőt Fujian tartományban. Fő félelmük az volt, hogy miután Japán az „északi előrenyomulás” (hokushin 北進) stratégia újabb fejezeteként Koreából megtámadta Mandzsúriát, majd sikeres elfoglalását követően létrehozta a Mandzsukuo (Manzhouguo 滿洲國) nevú bábállamot, csak idő kérdése a „déli előrenyomulás” (nanshin 南進) folytatása Taiwanról Fujian tartomány irányába. 1933-ban a Jiang Guangnai 蒋光費 által vezetett 19-edik hadsereget (shijiu lujun 十九路军), mely egyike volt a január 28-i incidens során a japánok ellen harcoló alakulatoknak, így jelentős presztízse volt a lakosság körében, a központi kormány Fujianbe rendelte egy kommunista felkelés leverésére. Jiang Guangnai a régió egyéb, a nankingi kormánnyal elégedetlen katonai és civil vezetőivel szövetkezve kihasználta az alkalmat, és fellázadt a központi hatalom ellen, Fuzhouban megalakítva a Kínai Köztársaság Népi Forradalmi Kormányát. A tengerentúli kínaiak a lázadó kormány oldalára álltak, befolyásos vezetőik, mint Li Qingquan megpróbálták

$\overline{44 \text { He 2015: 112-121. }}$. 
a lehető legnagyobb mennyiségú anyagi és morális támogatást összegyújteni a tengerentúli közösségekben a lázadó kormány számára. Míg a fülöp-szigeteki kínai közösségekben relatív nagy támogatást ért el az újonnan alapított kormány, máshol inkább értetlenség és megosztottság fogadta az eseményeket, különösen, miután elterjedt, hogy Fuzhouban a lázadó vezetés elkezdte eltüntetni Sun Yat-sen képeit és a köztársasági jelképeket a középületekről. A fujiani lázadást 1934-ben leverték a Guomindang csapatai, s annak vezetói, támogatói nagyrészt menekülni kényszerültek Kínából, a tengerentúli vezetôk egy jelentős része pedig visszavonulni a szárazföldi politikából ${ }^{45}$ Sok szempontból ez jelentette a tengerentúli kínai aranykor végét Xiamenben, hatása azonban - különösen várostervezési szempontból - a mai napig érezhető Xiamenben és környékén.

\section{Konklúzió: Gulangyu fejlődési folyamatának egyedisége}

Ahogy Fei Chengkang 费成康 Zhongguo zujie shi 中国租界史 (Kina külföldi koncesszióinak története) címú múvében leírja, számos külföldi koncesszió múködött Kínában az elsô ópiumháború és a második világháború között, de közülük csak négy - Tianjin, Hankou 汉口 (a mai Wuhan 武汉), Shanghai és Xiamen - koncessziós területei tudtak gazdasági hatásukon kívül jelentôs kulturális hatást kifejteni a határaikon belül és kívül éló lakosságra. ${ }^{46}$ A Shanghaiban és Gulangyun található közös koncessziók különlegesek voltak egyrészt olyan szempontból, hogy több ország közös irányítása alatt múködtek, szemben a Tianjinben és Hankouban egymással határos, de külön-külön országok irányítása alá tartozó konceszsziós területekkel. He Qiying összehasonlítást tesz a Shanghaiban és a Gulangyun található koncessziós területek közt. Ahogy megjegyzi, Gulangyu adminisztrációs rendszere a Shanghai Nemzetközi Településén alapult, de gazdasági és kulturális téren soha nem szerzett ahhoz hasonló befolyást. ${ }^{47}$ Bizonyosan igaz, hogy Gulangyu nem volt képes olyan hatással lenni Kína

45 Cook 1998: 398-435.

46 Fei 1990: 267.

47 He 2007: 215-237. 
egészére, mint az 1920-30-as években Kína gazdasági és kulturális fellegvárává váló Shanghai központjában található megfelelője. Ugyanakkor, ahogy azt J. A. Cook PhD értekezésében is kifejti, speciális földrajzi helyzete és migrációs történelme okán Xiamen egyedi, tengerentúli kínaiak által kezdeményezett modernizációs folyamaton ment keresztül a 20. század elején. Ennek az „alternatív modernizációnak” pedig, ahogy a tanulmányban bemutatásra került, az apró Gulangyu sziget volt az epicentruma.

Gulangyu fejlődését nyelvi és kulturális szempontból vizsgálva megállapíthatjuk, hogy mindez egy egyedi, a Dél-kínai-tenger régiójához kötődő interakciós folyamat része volt, mely a 19. század elején a délkelet-ázsiai gyarmatokon kezdődött a nyugatiak és a hokkien nyelvú kínai közösségek kapcsolatba kerülésével. Miután Kína az első ópiumháborút lezáró egyenlőtlen szerződések részeként kénytelen volt megnyitni Xiament a külföld felé, a hittérítók ebben jó lehetőséget láttak arra, hogy a kereszténység terjesztését a hokkienül beszélő́k felmenőinek földjén folytassák. A hittérítők jelenléte Gulangyun nem csupán az írott minnan dialektus fejlôdésének következő állomását jelentette, hanem az angol nyelvú modern oktatás korai központjává is tette Kínában. Ez a 20. század elején a Kínába visszatérő tengerentúli kínaiak nagyszámú letelepedéséhez vezetett a szigeten, akik szintén jelentős mértékben hozzájárultak a terület további modernizációjához. Később, Kína egésze és különösen felmenőik földje, Dél-Fujian iránti patrióta érzelmek által vezérelve a modernizációs folyamatok fó támogatóivá váltak, ami jelentős hatással volt Xiamen és környéke fejlődésére a 20. század első évtizedeiben.

Az utóbbi évtizedekben, ahogy a kínai tudományos életben egyre objektívabb diskurzus folyik a második világháború előtti Kína és a külföld kapcsolatáról, az érdeklődés a volt koncessziós területek iránt is új lendületet kapott. Az elmúlt húsz évben kínai nyelven viszonylag sok új anyag jelent meg Gulangyuvel kapcsolatban, angol nyelven ugyanakkor az átfogó másodlagos források továbbra is néhány MA és $\mathrm{PhD}$ értekezésre korlátozódnak. Nem meglepő módon magyarul eddig nem született Gulangyuvel foglalkozó tanulmány. Különleges építészeti stílusával Gulangyu Kína-szerte népszerú 
turistacélpontnak számít. Az UNESCO világörökségi státuszra történő 2010es pályázásával elképzelhetô, hogy külföldön is nagyobb hírnevet szerez ez a merőben egyedi történelemmel rendelkező sziget.

\section{Felhasznált irodalom}

\section{Elsődleges források}

Brown, William N. (ed.) 2010. Old Gulangyu in Foreigners' Eyes. Xiamen: Xiamen University Press.

Doty, Elihu 1853. Anglo-Chinese Manual of the Amoy Dialect. Guangzhou: Samuel Wells Williams.

Giles, H. Allen 1878. A Short History of Koolangsu. Amoy: A. A. Marcal.

Gulangyu wenshi ziliao 鼓浪屿文史资料 [Gulangyui irodalmi és történeti anyagok] Vols. 1-10, 1995-2003. Szerk.: Zhongguo Renmin Zhengzhi Xieshang Huiyi Xiamen shi Gulangyu qu Weiyuanhui 中国人民 政治协商会议厦门市鼓浪屿区委员会 [Kínai Népi Politikai Tanácskozó Testület Xiamen Város Gulangyu Kerületi Tanácsa]. Xiamen.

Gulangyu wenshi ziliao 鼓浪屿文史资料 [Gulangyui irodalmi és történeti anyagok] Vols. 1-3, 2010. Szerk.: Gulangyu Shenbao Shijie Wenhua Yichan Xilie Congshu Bian Weihui 鼓浪屿申报世界文化遗产系列 丛书编委会 [Sorozat Gulangyu UNESCO világörökségi státusz pályázata alkalmából, szerkesztői bizottság], Xiamen.

Lee Kuan Yew 2000. From Third World To First - The Singapore Story: 1965-2000. Singapore: Times Media Private Limited.

Lim Boon Keng 1904. „Ethical Education for the Straits Chinese.” Straits Chinese Magazine VIII.1: 25-30.

MacGowan, John 1869. A Manual of the Amoy Colloquial. Hong Kong: de Souza \& Co. 
Medhurst, W. Henry 1832. Dictionary of the Hok-këèn Dialect of the Chinese Language, According to the Reading and Colloquial Idioms. Macau: East India Press.

Pitcher, Philip Wilson 1912. In and about Amoy. Some historical and other facts connected with one of the first open ports in China. (Second Edition.) Shanghai and Foochow: The Methodist Publishing House in China.

Wang Fangwen 汪方文 (fószerk.) 1996. Jindai Xiamen jiaoyu dang'an ziliao 近代厦门教育档案资料 [Dokumentumok a modernkori Xiamen oktatásáról]. Xiamen: Xiamen Daxue Chubanshe.

Xiamen wenshi ziliao 厦门文史资料 [Xiameni irodalmi és történeti anyagok] Vols. 1-22. 1963-2000, szerkesztő: Zhongguo Renmin Zhengzhi Xieshang Huiyi Fujian sheng Xiamen shi Weiyuanhui Wenshi Ziliao Yanjiu Weiyuanhui 中国人民政治协商会议福建省厦门市委员会文 史资料研究委员会 [Kínai Népi Politikai Tanácskozó Testület Fujian Tartomány Xiamen Városi Tanácsa, Irodalmi és Történelmi Anyagok Kutatóbizottsága], Xiamen.

\section{Másodlagos szakirodalom}

Cook, James Alexander 1998. Bridges to Modernity: Xiamen, Overseas Chinese and Southeast Coastal Modernization, 1843-1937. (PhD thesis, University of California, San Diego)

Fei Chengkang 费成康 1990. Zhongguo zujie shi 中国租界史 [A kínai koncessziós területek története]. Shanghai: Shanghai Shehui Kexueyuan Chubanshe.

He Bingzhong 何丙仲 2010. Gulangyu gonggong zujie 鼓浪屿公共租界 [A Gulangyu Közös Koncesszió]. (Gulangyu Lishi Wenhua Xilie 鼓浪 屿历史文化系列 [Gulangyu története és kultúrája sorozat]) Xiamen: 
Xiamen Daxue Chubanshe.

He Qiying 何其颖 2007. Gonggong zujie Gulangyu yu jindai Xiamen de fazhan 公共租界鼓浪屿与近代厦门的发展 [A Gulangyu Közös Koncesszió és az újkori Xiamen fejlődése]. Fuzhou: Fujian Renmin Chubanshe.

He Shubin 何书涁 2015. „'Minqiao jiuxiang yundong’: Gulangyu guiqiao jingying de yici shehui gailang meng “闽侨救乡运动” : 鼓浪屿归 侨精英的一次社会改良梦 [“A fujiani tengerentúli kínaiak falumentô mozgalma’: A gulangyui hazatéró tengerentúliak kiválóságainak álma a társadalmi reformért].” Gulangyu yanjiu 鼓浪屿研究 1: 113-122.

Hong Buren 洪卜仁 一 Zhan Zhaoxia 詹朝霞 2011. Gulangyu xuezhe 鼓 浪屿学者 [Gulangyu tudósai]. (Gulangyu Lishi Wenhua Xilie 鼓浪 屿历史文化系列 [Gulangyu története és kultúrája sorozat]) Xiamen: Xiamen Daxue Chubanshe.

Lin Quan 林泉 (szerk.) 2002. Fujian tianzhujiao shi jiyao 福建天主教史纪 要 [Összefoglaló a katolikus egyház történetéről Fujianben]. Fuzhou: Fujian sheng Tianzhujiao Lianghui.

Liu Shiyan 刘世岩 2013. A Concise Book of Xiamen Peh-oe-ji / Xiamenhua baihuazi jianming jiaocheng 厦门话白话字简明教程 (kétnyelvű). Xiamen: Gulangyu Shenbao Shijie Wenhua Yichan Xilie Congshu 鼓 浪屿申报世界文化遗产系列丛书 [Sorozat Gulangyu UNESCO világörökségi státusz pályázata alkalmából].

Long Ming 龙鸣 — Jing Dongsheng 景东升 (szerk.) 2013. Guangzhouwan shiliao huibian 广州湾史料汇编 [Guangzhouwani történeti anyagok gyújteménye]. Guangzhou: Guangdong Renmin Chubanshe. 
Rigger, Manuel 2015. German Involvement in Xiamen After the First Opium War 1842-1917, MA thesis, Xiamen University (http://www.manuelrigger.at/xiamen/thesis.html, utoljára megtekintve: 2016. május 14.).

Tan Yeok Song 陈育崧 (szerk.) 1970. Lin Wenqing zhuan 林文庆传 [Lim Boon Keng élete]. (Lin Wenqing boshi dansheng bai nian jinian kan 林文庆博士诞生百年纪念刊 [Emlékkiadvány Dr. Lim Boon Keng szuiletésének 100. évfordulója alkalmából]), Singapore: Amoy University Alumni.

Wang Hai 王海 2015. ,Zhanqian Riben zai Xia renkou zhuangkuang (19261937 nian) 战前日本在厦人口状况 (1926-1937年) [A háború előtti xiameni japán lakosság helyzete (1926-1937)].” Gulangyu yanjiu 鼓 浪屿研究 1: 50-58.

Woodbridge, David 2015a. ,Gulangyu lishi - Zaoqi yangren juzhu de xiangguan ziliao 鼓浪屿历史 - 早期洋人居住的相关资料 [Gulangyu története - A korai külföldi lakosokkal kapcsolatos anyagok]." Gulang$y u$ yanjiu 鼓浪屿研究 1:25-41.

Woodbridge, David 2015b. „The International Settlement on Gulangyu.” Gulangyu yanjiu 鼓浪屿研究 2: 1-30.

Xu Chang'an 许长安 2000. Yuwen xiandaihua xianqu Lu Zhuangzhang 语 文现代化先驱卢意系章 [A nyelvi és írásreform úttörője, Lu Zhuangzhang]. Xiamen: Xiamen Daxue Chubanshe.

Xu Shifang 许十方 - C Cheng Feng 陈峰 2012. Gulangyu jiaoyu 鼓浪屿教 育 [Gulangyu oktatása]. (Gulangyu Lishi Wenhua Xilie 鼓浪屿历史 文化系列 [Gulangyu története és kultúrája sorozat]) Xiamen: Xiamen Daxue Chubanshe.

Zhan Shichuang 詹石窗 —- Lin Anwu 林安悟 (főszerk.) 2007. Minnan zongjiao 闽南宗教 [Vallások Dél-Fujianben]. Fuzhou: Fujian Renmin Chubanshe. 